\title{
ABDOMINAL CONTRAST ENHANCED ULTRASOUND, A PRACTICAL REVIEW
}

\author{
Adina Cociorvei \\ Elias Emergency Hospital Bucharest \\ Correspondent author: adinacociorvei@yahoo.com
}

\section{Rezumat}

Ecografia abdominală cu contrast (CEUS) este o metodă de examinare relativ nouă, care combină examinarea ecografică tradițională cu injectarea unei cantități foarte mici de substanță de contrast într-o venă periferică (de obicei vena cubitală). Substanța de contrast folosită este compusă din microbule de gaz stabilizate într-o suspensie de fosfolipide. Dimensiunile microbulelor sunt foarte mici, cuprinse între 1-10 micrometri, fiind prea mari pentru a ieși din vasele de sânge, dar suficient de mici pentru a pătrunde în microcirculația capilară, și pot fi folosite ca trasori vasculari. Astfel, este posibilă evidențierea microvascularizației organelor parenchimatoase în diferite faze vasculare, imagini similare celor obținute la examinarea CECT și CEMRI.

Substanța de contrast se elimină prin plămâni în timpul expirației și, din această cauză, principala contraindicație pentru folosirea ei o reprezintă pacienții cu insuficiență respiratorie severă. De asemenea, substanța de contrast nu determină reacții alergice, procentul de reacții alergice raportate la numarul de cazuri fiind extrem de redus (0,001\%).

Cele mai importante avantaje ale metodei sunt:

- poate fi folosită în siguranță pentru pacienții alergici la substanțele de contrast cu administrare intravenoasă folosite la CECT și CEMRI

- poate fi folosită și la pacienții la care substanța de contrast intravenoasă nu se poate administra din cauza bolii renale cronice.

Ecografia abdominală cu contrast este folosită cel mai frecvent în practică pentru evaluarea formațiunilor tumorale hepatice, dar și pentru patologia tumorală pancreatică, renală, testiculară, precum și în bolile inflamatorii intestinale.

Cuvinte cheie: ecografie cu contrast, microbule, microvascularizație, non-alergenic, tumori hepatice. 


\title{
INTERNAL
}

\section{General Reviews}

\begin{abstract}
Abdominal contrast enhanced ultrasound (CEUS) is a relatively new investigation method that combines conventional ultrasound with a small amount of intravenous contrast through a peripheral vein (usually the cubital vein). The contrast is made by very small gas microbubbles floating in a phospholipid suspension. The size of microbubbles are between 1-10 micrometers, being to large to go out of the vessels, but sufficiently small to stay into the capillaries, and this is the reason for they can be used as vascular tracers. So, it is possible to obtain images with microvessels inside of different organs in different vascular phases (arterial, portal, venous), images that are similar with the one obtained in CECT and CEMRI.

The intravenous contrast used in CEUS eliminates trough the lungs, during expiration. These is the reason why the most important contraindication for using iv contrast is severe respiratory failure. Also, it is important that intravenous contrast is not allergenic, the percentage of allergic reaction being extremly small $(0,001 \%)$.

The most important advantages of CEUS are:

- It can be safely used for the pacients that are allergic to intravenous contrast used in CECT and CEMRI;

- It can be used in pacients with chronic kidney disease;

Abdominal contrast enhanced ultrasound is used in day-to-day practice mainly for evaluation of hepatic lesions, but also for pancreatic, kidney, testis pathology, as well as for inflammatory bowel diseases.
\end{abstract}

Keywords: contrast ultrasound, microbubbles, microvessels, non-allergenic, liver tumors. 
Contrast-enhanced ultrasound (CEUS) is the application of ultrasound contrast medium to traditional medical sonography. Ultrasound contrast agents rely on the different ways in which sound waves are reflected from interfaces between substances. This may be the surface of a small air bubble or a more complex structure. Commercially available contrast media are gas-filled microbubbles that are administered intravenously to the systemic circulation. Microbubbles have a high degree of echogenicity (the ability of an object to reflect ultrasound waves). There is a great difference in echogenicity between the gas in the microbubbles and the soft tissue surroundings of the body. Thus, ultrasonic imaging_using microbubble contrast agents enhances the ultrasound backscatter, (reflection) of the ultrasound waves, to produce a sonogram_with increased contrast due to the high echogenicity difference. Contrast-enhanced ultrasound can be used to image blood perfusion in different organs. Contrast-enhanced ultrasound is regarded as safe in adults, comparable to the safety of MRI contrast agents, and better than radiocontrast agents_used in contrast CT scans. A true benefit is seen in patients with contraindications for CECT or CEMRI, such as renal failure or claustrophobia ${ }^{(1)}$.

The more limited safety data in children suggests that such use is as safe as in the adult population. Also, there are limited data regarding the use of CEUS in pregnancy and breastfeeding(2). An informed consent must be obtained before performing CEUS.

The microbubble contrast agents has the following general features:

- Microbubble shell: selection of shell material determines how easily the microbubble is taken up by the immune system. A more hydrophilic material tends to be taken up more easily, which reduces the microbubble residence time in the circulation. This reduces the time available for contrast imaging. The shell material also affects microbubble mechanical elasticity. The more elastic the material, the more acoustic energy it can withstand before bursting. Currently, microbubble shells are composed of albumin, galactose, lipid, or polymers.

- Microbubble gas core: The gas core is the most important part of the ultrasound contrast microbubble because it determines the echogenicity. When gas bubbles are caught in an ultrasonic frequency field, they compress, oscillate, and reflect a characteristic echo- this generates the strong and unique sonogram in contrast-enhanced ultrasound. Gas cores can be composed of air, or heavy gases like perfluorocarbon, or nitrogen. Heavy gases are less water-soluble so they are less likely to leak out from the microbubble leading to microbubble dissolution. As a result, microbubbles with heavy gas cores last longer in circulation.

- Regardless of the shell or gas core composition, microbubble size is uniform. They lie within a range of 14 micrometres in diameter. That makes them smaller than red blood cells, which allows them to flow easily through the circulation as well as the microcirculation(3).

The most common used agent contains sulphur hexachloride microbubbles (SonoVue Bracco company). It is mainly used to characterize liver lesions that cannot 


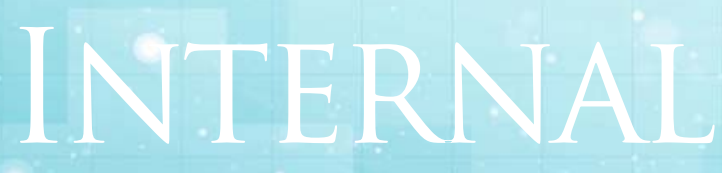

\section{General Reviews}

be properly identified using conventional (bmode) ultrasound. It remains visible in the blood for 3 to 8 minutes, and is expired by the lungs(4).

There are two forms of contrast-enhanced ultrasound, untargeted (used in the clinic today) and targeted (under preclinical development). The two methods slightly differ from each other.

\section{Untargeted CEUS}

Untargeted microbubbles, such as SonoVue are injected intravenously into the systemic circulation in a small bolus. The microbubbles will remain in the systemic circulation for a certain period of time. During that time, ultrasound waves are directed on the area of interest. When microbubbles in the blood flow past the imaging window, the microbubbles' compressible_gas cores oscillate_in response to the high frequency sonic energy field, as described in the ultrasound article.

The microbubbles reflect a unique echo_that stands in stark contrast to the surrounding tissue due to the orders of magnitude mismatch between microbubble and tissue echogenicity. The ultrasound system converts the strong echogenicity into a contrast-enhanced image of the area of interest. In this way, the bloodstream's echo is enhanced, thus allowing the clinician to distinguish blood from surrounding tissues.

\section{Targeted CEUS}

Targeted contrast-enhanced ultrasound works in a similar fashion, with a few alterations. Microbubbles targeted with ligands that bind certain molecular markers that are expressed by the area of imaging interest are still injected systemically in a small bolus. Microbubbles theoretically travel through the circulatory system, eventually finding their respective targets and binding specifically. Ultrasound waves can then be directed on the area of interest. If a sufficient number of microbubbles have bound in the area, their compressible gas cores oscillate in response to the high frequency sonic energy field. The targeted microbubbles also reflect a unique echo that stands in stark contrast to the surrounding tissue due to the orders of magnitude mismatch between microbubble and tissue echogenicity. The ultrasound system converts the strong echogenicity into a contrast-enhanced image of the area of interest, revealing the location of the bound microbubbles. Detection of bound microbubbles may then show that the area of interest is expressing that particular molecular marker, which can be indicative of a certain disease state, or identify particular cells in the area of interest ${ }^{(5)}$.

From a practical point of view, intravenous access on the left antecubital vein, by at least a 20-gauge cannula, is preferred. The 
injection of UCA ( 1 - $2.4 \mathrm{ml} /$ examination for liver CEUS) is followed by a $10 \mathrm{ml}$ saline flush. A timing counter on the ultrasound machine should be available to monitor the vascular phases described for the liver: arterial phase - starting 10 seconds after the contrast bolus, lasting 30 seconds; portal phase: $30-$ 120 seconds following the contrast bolus; and the late phase, starting 120 seconds following the contrast bolus, lasting until the total disappearance of the bubbles ${ }^{(6)}$. Only two phases, arterial phase - starting 10-15 seconds from contrast bolus, and venous phase - starting 30 seconds following contrast bolus, are described for other organs (spleen, pancreas, gastrointestinal (GI) tract wall, etc). The enhancement patterns of structures evaluated by CEUS are described as hyper-, iso-, hypo-, or nonenhancing as compared with the surrounding tissues. In Romania, CEUS is used more in more in the last years, and in 2017 a medical team published National Guidelines on CEUS in clinical practice ${ }^{(7)}$.

The most important pathology in which we can use CEUS is liver pathology, but is not the only one. CEUS is used more and more also in pancreatic diseases (tumors, acute pancreatitis), for kidney (solid renal tumors, benign and malignant, cystic renal tumors, renal infection, disorders of the renal blood supply, transplant), testis diseases (inflammation, trauma, tumors, torsion), inflammatory bowel diseases, acute bowel ischemia and necrosis, acute diverticulitis. CEUS is used also and can provide significant diagnostic aid in blunt abdominal trauma.

CEUS must be performed always after conventional and Doppler ultrasound examination, and must be used for only a specific lesion. On the following we will describe briefly the most common indications for the use of abdominal CEUS.

\section{Liver}

1. Hemangiomas are the most common benign liver tumors. On conventional US examination hemangiomas had an homogenous echogenic pattern with clear edges. The typical CEUS pattern is with enhancement in the periphery in the arterial phase and an centripetal fill-in, and with persistent hiper or iso enhancemenent during the late phase with no wash out ${ }^{(6)}$. The specificity can be as high as $99 \%{ }^{(8)}$.

2. Focal nodular hyperplasia (FNH) is the second most common benign liver tumor. It is considered to be a congenital vascular malformation an it is unifocal in the majority of cases. On conventional US examination, the B-mode appearance of FHN is normally hyperechogenic and color an power Doppler show the spoke-wheel pathognomonic pattern. On CEUS examination, in the arterial phase, we can describe two types of findings: the "classical type" in which we have a rapid fill-in from the centre outwards in a spokewheel pattern with a central scar, and the "eccentric type" in which CEUS shows twisted vessels, but in this case the central point is shifted eccentrically to the edge of the lesion. In the portal and late phase the lesion remains hiper- or iso-enhancing, with no wash-out.The sensitivity was $88 \%$ in the Friedrich -Rust meta- analysis and the specificity can be as higher as $100 \%{ }^{(9,10)}$.

3. Focal fatty liver lesions. On conventional US fatty liver lesions can be hyperechoic areas (focal steatosis) in a normal liver or hypoechoic areas (focal sparing) in a fatty liver. On CEUS those areas are iso-enhancing in comparison to the surrounding liver in all vascular phases, with no wash out ${ }^{(6)}$.

4. Adenomas is a rare benign liver tumor, and appears mostly in younger women with a 
history of oral contraceptives use. On conventional US examination the B-mode appearance is inconsistent, and can be hyper-, hypo-, or isoechoic. On CEUS adenoma usually appears to be with hyperenhancement from periphery with centripetal filling. In the portal phase it remains iso-or hyperechoic, but sometimes in the late phase wash-out can occur, thus being false positive for malignancy ${ }^{(6)}$. Adenomas often needed guided biopsy for a definite diagnosis.

5. Hepatocellular carcinoma (HCC) is a primary malignant hepatic tumor developed mostly in a pacient with a chronic liver disease (70-90\%). In a cirrhotic liver, the possibility of HCC increases with nodule size. Nodules with less than $1 \mathrm{~cm}$ in diameter are rarely malignant and US follow-up is recommended.

On conventional US, HCC appears like an illdefined iso- or hyper-echoic nodule, variable in size, with intralesional vascularity on color Doppler. On CEUS, HCC is often hyperenhancing in the arterial phase, with a chaotic pattern, and with late or very late wash-out, the timing of wash-out being correlated with the differentiation of the tumor.

The examination with CEUS for HCC must be at least 4 to 6 minutes long. For the examination, specific algorithms have been developed, such as CEUS LI-RADS ${ }^{(10)}$.

\section{Intrahepatic cholangiocarcinoma} (ICC) is a malignant tumor derived from the intrahepatic bile ducts, usually occurring in a non-cirrhotic liver. On conventional US, ICC appears as a ill-defined tumor with hypoechoic aspect, and the imaging diagnosis is difficult. On CEUS, the most common aspect is a rim-like hyperenhancing lesion in the arterial phase, with early washout in the portal phase ${ }^{(11,12)}$. In a Romanian multicentre study, CEUS had $60 \%$ sensitivity, $85,1 \%$ specificity and $83,9 \%$ accuracy for diagnosing $\mathrm{ICC}^{(7,13)}$.

7. Liver metastases. The typical US appearance is of a "target" lesion that can be hyper-or hypo-echoic. ON CEUS most liver metastases are hypoenhancing in the arterial phase, sometimes with a rim enhancement, but they can be hypervascular with hyperenhancing in the arterial phase, also. Characteristic for the majority of liver metastases is early and progressive wash-out, started at the end of the arterial phase ${ }^{(6)}$.

8. Liver abscess. In the case of liver abscess the US appearance varies, and usually is a hypo-anechoic mass with thick walls, internal septum and sometimes gas inside. CEUS criteria for the diagnosis of liver abscesses are:marginal rim enhancement in the arterial phase, with enhancement of the septa due to inflammation (honeycomb appearance) with anechoic liquid areas. During the venous 
phase, hypoenhancement of the wall and septa can be seen ${ }^{(6)}$. CEUS is helpful to find avascular areas inside the abscess in order to guide percutaneous drainage ${ }^{(7,14)}$. In a Romanian multicentre study, CEUS had 76,9\% sensitivity, $88,9 \%$ specificity, and $86,9 \%$ accuracy to diagnose liver abscesses ${ }^{(13)}$.

\section{Pancreas}

\section{Solid focal pancreatic lesions.}

Pancreatic ductal adenocarcinoma is usually hypoenhancing in the early phase as compared to the adjacent pancreatic tissue ${ }^{(20,21)}$. CEUS also allows a better delineation of the tumor and the assessment of vascular invasion(20). By contrast, neuroendocrine tumors have an intense enhancement in the arterial phase ${ }^{(22)}$. For both types of lesions, CEUS is useful for detecting liver metastases in the late phase ("wash-out" of liver lesions).

\section{Cystic focal pancreatic lesions. CEUS}

is useful for the differential diagnosis between pseudocysts, which are completely nonenhancing during CEUS, as opposed to cystic tumors, where the cystic wall, as well as the septa and protrusions will enhance after the contrast bolus ${ }^{(23)}$.

3. Acute pancreatitis CEUS can be used in acute pancreatitis (when the pancreas is well seen on conventional US) and reveals necrotic areas as nonenhancing ones. Several studies confirmed the value of CEUS for detecting pancreatic necrosis and for predicting the severity of AP, with sensitivity ranging from $82 \%$ to $90.3 \%$ and specificity from $89 \%$ to $98.8 \%{ }^{(24,25)}$.

\section{Kidney}

Kidney CEUS ia a safe diagnostic method especially in patients with renal dysfunction ${ }^{(7)}$.
1. Solid renal tumors. It sometimes may be difficult to differentiate "real" renal tumors from so-called pseudotumors, and CEUS is considered highly effective for this indication ${ }^{(28)}$.The enhancement pattern of pseudotumors mirrors must be the same like that of the surrounding tissues in all phases. Any other enhancing pattern should be considered suspicious for malignancy ${ }^{(15,28)}$. The most common benign renal tumors are angiomyolipoma and oncocytoma. Benign tumors typically show no enhancement. In the case of malignant tumors, in renal cell carcinoma (RCC) the typical pattern is with rapid hyper-enhancement in the arterial phase, followed by wash-out. The differentiation between RCC and other benign tumors is difficult and therefore CEUS alone is not recommended ${ }^{(16)}$

2. Cystic renal tumors. Cysts can present as equivocal, complex, or hyperdense and require differentiation of malignant from benign. The Bosniak classification system modified for CEUS evaluates the cystic lesions in terms of quantity, thickness and enhancement of walls and septa ${ }^{(17)}$. CEUS can identify more septa, characterize them as thicker and pick up solid components within cystic lesions at least as accurately as $\mathrm{CT}^{(7)}$.

3. Renal infection. Renal abscesses demonstrate central non-enhancement in all phases. CEUS is as good as CT for diagnosing uncomplicated pyelonephritis, demonstrating focal pyelonephritis as a "wedge-shaped" or round region of hypoenhancement, best seen in the late parenchymal phase ${ }^{(7,16)}$.

\section{Disorders of the renal blood supply.} CEUS is an effective and reproducible method for detecting acute renal infarction, with accuracy comparable to CT. On CEUS it appears as a "wedge-shaped" area of nonperfusion; cortical necrosis appearance 


\section{INTERNAL}

\section{General Reviews}

is similar, but with preserved hilar vascularity ${ }^{(7,14,15,18)}$.

5. Kidney transplant. CEUS may assess vascular dynamics to predict graft success or failure: if the allograft does not enhance or lacks cortical or regional enhancement, this may indicate an inflow or outflow problem ${ }^{(19)}$.

\section{Testis}

In the case of testis pathology, CEUS is very useful for evaluating testicular torsion and inflammations (orchitis, epididymitis), including abscesses. In testicular tumors, CEUS is useful in the discrimination between cysts (no enhancement) and solid tumors, but there is no specific pattern in relation with the tumor type.

In testicular trauma the hematoma is anechoic on conventional US and with no enhancement on CEUS ${ }^{(7,26)}$.

\section{Inflammatory bowel diseases}

CEUS is used mainly for Crohn disease, in the differentiation between active and inactive disease and in the diagnosis of Crohn disease complications. Also, CEUS is useful for the differential diagnosis between inflammatory pseudo-tumors (intense enhancement within the lesion and in the peripheral tissue) and abscesses (peripheral enhancement without enhancement within the lesion). The usefulness and practical applicability of CEUS in ulcerative colitis is less defined so $\operatorname{far}^{(7)}$.

CEUS is also useful for the diagnosis of acute bowel ischemia and necrosis (irrespective of the cause), suggested by the lack of, or diminished enhancement of the bowel wall. CEUS can be used in complicated acute diverticulitis to differentiate between phlegmonous and abscessed areas, or to guide percutaneous drainage of a peridiverticular collection ${ }^{(27)}$.

\section{Conclusions}

CEUS is a very useful method for the examination of a suspicious lesion, especially for patients with allergies at iv contrast substances used for CECT and CEMRI, or with chronic kidney disease.

CEUS has a few important advantages:

- Contrast agents are chemically inert and not allergenic, so they can be used more than once during one examination

- The contrast agent is a gas that eliminates trough the lungs, during expiration, so it can be used almost always, with the exception of the pacients with severe respiratory failure and for those who are in the first two weeks after an acute myocardial infarction; the method it is 
also not recommended for pregnant women

- The contrast agents are very well tolerated, so there was only a small percentage $(0,001 \%)$ of severe side effects when abdominal CEUS is performed

- The duration for an examination is very short (8-10 minutes maximum), with no discomfort for the patient

\section{References:}

1.Strobel D, Seitz K, Blank W, et al. Contrast-enhanced ultrasound for the characterization of focal liver lesions diagnostic accuracy in clinical practice (DEGUM multicenter trial). Ultraschall Med 2008;29:499-505.

2. Sidhu, Paul; Cantisani, Vito; Deganello, Annamaria; Dietrich, Christoph; Duran, Carmina; Franke, Doris; Harkanyi, Zoltan; Kosiak, Wojciech; Miele, Vittorio; Ntoulia, Aikaterini; Piskunowicz, Maciej; Sellars, Maria; Gilja, Odd (2016). "Role of Contrast-Enhanced Ultrasound (CEUS) in Paediatric Practice: An EFSUMB Position Statement". Ultraschall in der Medizin European Journal of Ultrasound. 38 (1): 33-43.

3. Lindner J.R. (2004). "Microbubbles in medical imaging: current applications and future directions". Nat Rev Drug Discov. 3 (6): 527-32.

4. "SonoVue, INN-sulphur hexafluoride-Annex 1Summary of Product Characteristics" (https://www.ema.europa.eu/documents/productinformation/sonovue-epar-product-information_en.pdf) European Medicines Agency. Retrieved 2019-02-24.

5. Klibanov A.L. (1999). "Targeted delivery of gas-filled microspheres, contrast agents for ultrasound imaging". Adv Drug Deliv Rev. 37 (1-3): 139-157.

6. Claudon M, Cosgrove D, Albrecht $T$, et al. Guidelines and good clinical practice recommendations for contrast enhanced ultrasound (CEUS) - update 2008. Ultraschall Med 2008;29:28-44.

7.Sporea I, Badea R, Brisc $C$, et al. Romanian National Guidelines on Contrast Enhanced Ultrasound in clinical practice. Med Ultrason 2017;19:401-415 DOI:10.11152/mu-1349

8. Fang L, Zhu Z, Huang B, et al. A comparative study of contrast enhanced ultrasound and contrast enhanced magnetic resonance imaging for the detection and characterization of hepatic hemangiomas. Biosci Trends 2015;9:104-110.

9. Trillaud H, Bruel JM, Valette PJ, et al. Characterization of focal liver lesions with Sonovue ${ }^{\circledR}$-enhanced sonography: International multicenter-study in comparison to CT and MRI. World J Gastroenterol 2009;15:3748-3756.

10. Roche V, Pigneur F, Tselikas L, et al. Differentiation of focal nodular hyperplasia from hepatocellular adenomas with low-mechanical-index contrastenhanced sonography (CEUS): effect of size on diagnostic confidence. Eur Radiol 2015;25:186-195.

11. . Xu HX, Lu MD, Liu GJ, et al. Imaging of peripheral cholangiocarcinoma with low-mechanical index contrastenhanced sonography and Sonovue: initial experience. JUltrasound Med 2006;25:23-33.

12. Chen $L D, X U H X$, Xie $X Y$, et al. Intrahepatic cholangiocarcinoma and hepatocellular carcinoma: differential diagnosis with contrast-enhanced ultrasound. Eur Radiol 2010;20:743-753.

13. Sporea I, Badea R, Popescu A, et al. Contrastenhanced ultrasound (CEUS) for the evaluation of focal liver lesions - a prospective multicenter study of its usefulness in clinical practice. Ultraschall Med 2014;35:259-266.

14. Popescu A, Sporea I, Şirli R, et al. Does Contrast Enhanced Ultrasound improve the management of liver abscesses? A single centre experience. Med Ultrason 2015;17:451-455.

15. Tenant SC, Gutteridge CM. The clinical use of contrast-enhanced ultrasound in the kidney. Ultrasound 2016;24:94-103.

16. Kazmierski B, Deurdulian C, Tchelepi H, Grant EG. Applications of contrast-enhanced ultrasound in the kidney. Abdom Radiol (NY). 2017 Aug 30, doi:10.1007/s00261-017-1307-0.

17. Bosniak MA. The Bosniak renal cyst classification: 25 years later. Radiology 2012;262:781-785.

18. Piscaglia F, Nolsøe C, Dietrich CF, et al. The EFSUMB Guidelines and Recommendations on the Clinical Practice of Contrast Enhanced UItrasound (CEUS): update 2011 on non-hepatic applications. Ultraschall Med 2012;33:33-59

19.Barr RG, Peterson C, Hindi A. Evaluation of indeterminate renal masses with contrast-enhanced US: a diagnostic performance study. Radiology 2014;271:133-142.

20. D'Onofrio M, Martone E, Malagò R, et al. Contrastenhanced ultrasonography of the pancreas. JOP 2007;8:71-76. 89.

21. Numata K, Ozawa $Y$, Kobayashi $N$, et al. Contrastenhanced sonography of pancreatic carcinoma: correlations with pathological findings. J Gastroenterol 2005;40:631-640.

22. D'Onofrio M, Mansueto $G$, Falconi M, Procacci $C$. Neuroendocrine pancreatic tumor: value of contrast enhanced ultrasonography. Abdom Imaging 2004;29:246-258.

23. 103. Rickes S, Wermke W. Differentiation of cystic 


\section{INTERNAL \\ General Reviews}

pancreatic neoplasms and pseudocysts by conventional and echo-enhanced ultrasound. J Gastroenterol Hepatol 2004;19:761- 766.

24. Rickes S, Uhle C, Kahl S, et al. Echo enhanced ultrasound: a new valid initial imaging approach for severe acute pancreatitis. Gut 2006;55:74-78.

25. Ripolles T, Martinez MJ, Lopez E, Castello I, Delgado F. Contrast-enhanced ultrasound in the staging of acute pancreatitis. Eur Radiol 2010;20:2518-2523.

26. . Yusuf GT, Sidhu PS. A review of ultrasound imaging in scrotal emergencies. JUltrasound 2013;16:171-178. 27. . Badea R, Socaciu M, Ciobanu L, Hagiu C, Golea A. Contrast-enhanced ultrasonography (CEUS) for the evaluation of the inflammation of the digestive tract wall. J Gastrointestin Liver Dis 2010;19:439-444.

28. Bertolotto M, Cicero C, Catalano O, Currò F, Derchi LE. Solid Renal Tumors Isoenhancing to Kidneys on Contrast-Enhanced Sonography: Differentiation From Pseudomasses. J Ultrasound Med 2017, Jul 29. doi:10.1002/jum.14335. 